\author{
Andrzej Jastrzębski OMI ${ }^{1}$ \\ Uniwersytet Świętego Pawła w Ottawie
}

\title{
Chrystocentryczny wymiar antropologii Hansa Ursa von Balthasara
}

\section{Streszczenie}

W niniejszym artykule autor nakreśla podstawowe cechy charakteryzujące rozumienie człowieka w myśli Hansa Ursa von Balthasara, według którego człowiek dochodzi do osiągnięcia prawdziwej pełni swego człowieczeństwa jedynie poprzez przyjęcie łaski odkupienia wysłużonej mu przez Chrystusa. Naśladowanie Chrystusa, które jest pierwotnym zadaniem człowieka odkupionego, jest w swej istocie przyjęciem i wypełnieniem otrzymanej od Boga Ojca życiowej misji. Przyjęcie tej misji i życie nią pozwala człowiekowi dotrzeć do pełni prawdy o sobie, tj. zrozumienia oraz przyswojenia swojej najgłębszej tożsamości jako bytu. Dalszą konsekwencją tego procesu jest dla człowieka jego spełnienie, a w końcu także osobista świętość. Ważnym kontekstem tego procesu jest modlitwa kontemplacyjna.

Słowa kluczowe: von Balthasar, antropologia, misja, odkupienie, świętość

\section{Summary}

Christocentric Dimension of the Anthropology of Hans Urs von Balthasar

In this article, the author outlines the basic features characterizing the understanding of the human being in the thought of Hans Urs von Balthasar, according to which we attain our true human fullness only by accepting the grace of redemption that Christ has gain for us. The imitation of Christ, which is the

1 AndrzejJastrzębski OMI(ORCID: 0000-0003-2637-7706) - dr hab. prof. USP, od 1999 roku prezbiter, teolog, filozof, absolwent studium psychoterapii i poradnictwa psychologicznego dla duchowieństwa KUL, dr filozofii KUL, licencjat z teologii duchowości KUL. Wykładowca na Papieskim Uniwersytecie Świętego Tomasza z Akwinu w interdyscyplinarnym programie STOQ (Science, Theology and the Ontological Quest) w Rzymie, na Uniwersytecie Adama Mickiewicza w Poznaniu, a obecnie na Uniwersytecie Świętego Pawła w Ottawie oraz w Podyplomowym Studium Duchowości KUL. Autor kilku książek oraz wielu artykułów i wystąpień w kontekście integralnego ujęcia człowieka w teologii, filozofii, psychologii, psychiatrii oraz psychoterapii. E-mail: andrzej.jastrzebski@oblaci.pl. 
primordial task of all the redeemed, is, in its essence a acceptance and fulfillment of the missionary vocation received from God. Accepting this mission and living it allows us to reach our full human potential, i.e. to bring about and assimilate our deepest identity as a human being. A further consequence of this process is selfactualization, and ultimately personal holiness. An important context for this process is contemplative prayer.

Keywords: von Balthasar, anthropology, mission, redemption, holiness

Nie ulega wątpliwości, że dorobek Hansa Ursa von Balthasara jest bardzo bogaty i w wielu miejscach niezwykle oryginalny. Inspiracje szwajcarskiego teologa sięgają daleko w historię myśli ludzkiej. Swoje inspiracje czerpie z dzieł św. Tomasza z Akwinu, św. Ignacego z Loyoli i idealistów niemieckich z Georgem Wilhelmem Friedrichem Heglem na czele, a w szczególności z pism Nikołaja Bierdiajewa, Ericha Przywary, Henriego de Lubaca, Adrienne von Speyer, czy Karla Bartha oraz egzystencjalistów takich, jak na przykład Martin Heidegger ${ }^{2}$. Z kolei sam von Balthasar stał się inspiracją dla wielu innych autorów ${ }^{3}$.

W niniejszym opracowaniu stawiamy sobie za cel naszkicowanie podstawowych cech charakteryzujących rozumienie człowieka w myśli von Balthasara. Uczynimy to w perspektywie inkarnacyjnej, to znaczy Wcielenia Słowa, Jezusa Chrystusa, który w pełni ukazał, co to znaczy być człowiekiem doskonałym. Dzięki spotkaniu z teorią rosyjskiego myśliciela Bierdiajewa, von Balthasar zaczął postrzegać rzeczywistość właśnie przez pryzmat wcielenia Syna Bożego, które stało się zwornikiem jego własnej refleksji w rozumieniu człowieka oraz trynitarnego wymiaru kosmosu'.

2 Por. A. Jastrzębski, Inspiracje teologii Hansa Ursa von Balthasara, „Filozofia Chrześcijańska" 13 (2016), s. 121-134.

3 Dla przykładu na gruncie polskim: S. Budzik, Dramat odkupienia, Tarnów 2007, E. Piotrowski, Toedramat, Kraków 1999, M. Pyc, Chrystus Piękno - Dobro - Prawda, Poznań 2002 czy B. Sawicki, Ekspresja jako spotkanie chrystologii i antropologii, Tyniec 2019.

4 J.S. King, C.M. Shea, The role of Nikolai Berdyaev in the early writings of Hans Urs von Baltasar: A contribution to the question of Balthasar's appropriation of sources, "Journal for the History of Modern Theology / Zeitschrift für Neuere Theologiegeschichte” 21 (2014) no.1, s. 230. 
W naszej analizie chcemy wyróżnić następujące elementy chrystocentryczności w antropologii von Balthasara. Po pierwsze, człowiek jest capax Dei, jest z natury wewnętrznie ukształtowany w taki sposób, aby odkryć obecność Boga w swojej ziemskiej egzystencji oraz obrać Go jako swój ostateczny cel. Po drugie, człowiek nadaje najgłębszy sens swojemu życiu, gdy na wzór Chrystusa odkrywa swoją misję, posłanie zlecone mu przez Boga Ojca, a następnie całym sercem ją wypełnia. Poprzez ten proces człowiek odkrywa równocześnie swoją prawdziwą tożsamość. Po trzecie, wcielenie Słowa Bożego stało się dla człowieka przyczyną wewnętrznej przemiany. Przez Chrystusa człowiek staje się nowym stworzeniem, otrzymuje nowe, duchowe zmysły: nowy smak, nowe spojrzenie oraz nowy słuch, a także nowy umysł. W końcu Chrystus objawia człowiekowi prawdziwy obraz tego, kim jest i kim może stać się człowiek odkupiony. Odkrycie swojego prawdziwego ja w Chrystusie jest zaproszeniem do wejścia na drogę ku świętości, co jest różnoznaczne z pełnieniem woli Ojca w taki sposób, w jaki czynił to Chrystus.

\section{Homo capax Dei}

Człowiek w ujęciu von Balthasara spontanicznie wchodzi w relację ze wszystkim, co istnieje, a ostatecznie także w relację z samym Stwórcą. Podczas tego procesu człowiek próbuje niejako „dostroić się” do rzeczywistości, przeżywając w konsekwencji zarówno momenty pasywności jak i aktywności, co nadaje jego relacjom znamię wzajemności. Człowiek najpierw doświadcza zewnętrznej „impresji”, tj., działania czegoś zewnętrznego wobec siebie, a następnie pojawia się moment ekspresji ja człowieka na zewnątrz. Co ważne, Bóg nie jest przy tym jakąś określoną doświadczalną zewnętrznością dla człowieka, ale raczej objawia się mu w głębi jego bytu, która naturalnie odnosi go do Boga, jako do swej podstawy i to najczęściej w sposób nieuświadomiony ${ }^{5}$. Von Balthasar

5 Por. H.U. von Balthasar, The Glory of the Lord, vol. 1: Seeing the Form, ed. E. Leiva-Meriikakis, San Francisco 1983, s. 245. 
potwierdza istotnie twierdzenie św. Tomasza z Akwinu, że „omnnia naturaliter appetunt Deum, non autem explicite"6.

Pomimo tego teolog szwajcarski spostrzega także trudności wiążące się przyjęciem koncepcji homo capax Dei:

Czy należy w ślad za Augustynem i Tomaszem ważyć się na koncepcję, że włączona w pierwotną postać stworzonego ducha, pobudzająca do oglądania Boga dynamika wytwarza „poszukujące” (Dz 17, 27) koncepcje, które wspierane i kierowane przez uprzednio już obecną łaskę (wzgl. Nadprzyrodzony egzystencjał), zmierzają w kierunku tego, czego nie można wytworzyć na zasadzie natury, aby następnie w zrządzonym drogą wolnej inicjatywy Boga, osądzającym i spełniającym zarazem Objawieniu znaleźć się na wyższym poziomie: „gratia non destruit sed elevat et perficit naturam” - zarazem jednak „,sanans naturam aegrotam”? W takim wypadku rezygnowałoby się z góry z hipotezy jakieś natura pura i zakładało jednocześnie dwie rzeczy: pozorny paradoks natury ukierunkowanej na nieosiągalne siłami przyrodzonymi pojęcie Boga oraz - przekraczając ten paradoks - włączoną już w „czysto naturalną” wolność łaskę Bożego samoodsłonięcia się, które wypływając z chrystologicznego centrum promieniuje na całą historię ${ }^{7}$.

Człowiek jest istotą teleologiczną, to znaczy, został stworzony ku pewnemu celowi (telos), którym jest spełnienie jego natury. Bóg stworzył człowieka w taki sposób, że jego natura może dojść do swej doskonałości, do swej prawdy, tylko poprzez kontemplację Chrystusa w modlitwie. Dla von Balthasara to, co do tej pory było określane najczęściej w naturze ludzkiej jako nadprzyrodzone, staje się częścią natury człowieka. Spełnienie natury ludzkiej dokonuje się, wedle teologa szwajcarskiego, w obrębie przyrodzoności człowieka ${ }^{8}$.

Von Balthasar jest przekonany, że poprzez widzenie i słuchanie Boga ludzka natura doświadcza najwyższej radości z bycia spełnioną w sobie samej, ale także z bycia wypełnioną czymś nieskończenie większym

6 Sancti Thomae de Aquino, De veritate, in: Quaestiones disputatae Opera omnia S. Thomae, textum Leonino 1976 edito adaequatum ac translatum a Roberto Busa SJ in taenias magneticas denuo recognovit Enrique Alarcón atque instruxit, q. 22, a. 2 (Corpus Thomisticum. Series Latina).

7 H.U. von Balthasar, Epilog, przekł. J. Zychowicz, Kraków 2010, s. 13.

8 V.S. Harrison, Homo Orans: von Balthasar's Christocentric Philosophical Anthropology, ,The Heythrop Journal" 40 (1999) Issue 3, s. 283, DOI: 10.1111/heyj.1999.40.issue-3. 
od siebie. Proces ten prowadzi do urzeczywistnienia się człowieka w swej naturze i do dojścia do stanu bycia błogosławionym?

W ujęciu von Balthasara potrzeba człowieka, która wyraża cel aktualizacji swej natury, nie jest niczym abstrakcyjnym, ale jest świadomie doświadczana przez każdego z nas w głębi swej istoty jako pragnienie celu oraz sensu życia - innymi słowy jako pragnienie odkrycia prawdy o sobie. Każdy człowiek głęboko odczuwa, że czegoś mu brakuje, ponieważ został stworzony w taki sposób, że nie może sam siebie zaspokoić, a prawdziwe spełnienie odnajduje jedynie w relacji z Bogiem. Zgodnie z chrystocentryczną antropologią von Balthasara każdy człowiek w czasie swego rozwoju, jeśli tylko jest wobec siebie szczery, dochodzi do momentu (niekoniecznie jednorazowego), kiedy odkrywa, że ostatecznej prawdy o sobie nie może znaleźć ani w przepaściach własnego ja, ani w świecie, który go otacza ${ }^{10}$.

Ostateczna Prawda i Najwyższe Dobro mogą być odnalezione tylko w Bogu, dlatego nie można ich znaleźć wewnątrz stworzonej natury ludzkiej. Oddzielanie się człowieka od Boga powoduje, że nie może on osiągnąć spełnienia swego bytu. Mimo to, nawet gdy człowiek oddala się od Boga przez grzech, wciąż w swej naturze pozostaje „zorientowany" w stronę swego ostatecznego celu, spełnienia w Chrystusie. W taki właśnie sposób działa łaska Boża ${ }^{11}$.

Von Balthasar twierdzi, że człowiek został stworzony, aby żyć w harmonii z Bogiem. W tym celu człowiek jest naturalnie predysponowany do modlitwy i bez ingerencji z zewnątrz nic nie powinno zakłócać w nim tego pragnienia. Harmonia między Bogiem a człowiekiem została zaburzona przez grzech, co ma także swoje reperkusje w życiu modlitwy, gdzie człowiek nie jest już spontanicznie całkowicie otwarty na Boga. W konsekwencji kontemplacja, przynajmniej w życiu ziemskim, może prowadzić do jedynie częściowego spełnienia potencjalności natury ludzkiej.

\footnotetext{
9 H.U. von Balthasar, Prayer, przekł. A.V. Littledale, London 1961, s. 21.

10 V.S. Harrison, Homo Orans: von Balthasar's Christocentric Philosophical Anthropology, dz. cyt., s. 284.

11 V.S. Harrison, Homo Orans: von Balthasar's Christocentric Philosophical Anthropology, dz. cyt., s. 285.
} 
Pełnię osiąga człowiek dopiero w życiu wiecznym. Pomocą w procesie oczyszczenia pragnień ludzkich jest łaska uświęcająca ${ }^{12}$.

Jednym ze znaków niemożliwości pełnego spełnienia się człowieka w rzeczywiści przyrodzonej jest odczuwanie lęku egzystencjalnego. Lęk ten, zdaniem von Balthasara, rodzi się w pustej przestrzeni, która otwiera się pomiędzy człowiekiem a Bogiem, w spotkaniu człowieka z Nieskończonym. Pustka przywołująca ten lęk powstaje w jego sercu wtedy, gdy oddala się od Boga i zwraca się ku własnemu ja. Ze względu na grzech pierworodny, który był takim właśnie odwróceniem się od Stwórcy, pustka doświadczana przez człowieka staje się doświadczeniem radyklanej nieobecności Pana. Brak wiary i zaufania Bogu w świadomym życiu człowieka skutkuje w taki sposób, że postrzega Boga jako obcą i zagrażającą mu obecność. Stąd łatwo się od Boga odwrócić. Co więcej, nawet Ci, którzy zwracają się ku tej Tajemniczej Obecności, doświadczają pewnej niemocy w przekroczeniu granicy lęku. Tak czy inaczej grzech tworzy zasłonę pomiędzy człowiekiem a Bogiem oraz pogłębia jego lęk egzystencjalny. Człowiek doświadczający lęku, zamiast utkwić swój wzrok w Bogu, przenosi go na siebie samego i na stworzony świat, sam czyniąc się miarą rzeczywistości. Gdy człowiek przestaje uznawać, że jest zależny od Boga, zaczyna się gubić i w konsekwencji tego zagubienia odczuwa jeszcze większy lęk. Pustka, która w ten sposób powstaje jest miejscem wypełnionym przez własne obsesje człowieka ${ }^{13}$.

Człowiek z jednej strony pragnie Najwyższego Dobra, ale z drugiej przybliżanie się do tego Dobra związane jest z trudem oczyszczania się ze skłonności egoistycznych, które popychają człowieka ku zachowaniu tego Dobra tylko dla siebie; zobowiązuje za to człowieka, aby sam stał się tym, który daje siebie. Stąd przyzwolenie na bycie obdarowanym pojawia się jedynie wówczas, gdy człowiek jest gotowy również ze swej strony bezinteresownie obdarowywać. Istotą dobra jest bowiem darowanie siebie $^{14}$.

12 V.S. Harrison, Homo Orans: von Balthasar's Christocentric Philosophical Anthropology, dz. cyt., s. 286-287.

13 A. Cirelli, Facing the Abyss: Hans Urs von Balthasar's reading of Anxiety, „New Blackfriars” 92 (2011) Issue 1042, s. 708, 711.

14 H.U. von Balthasar, Epilog, dz. cyt., s. 48, 50. 


\section{Prawdziwa tożsamość człowieka: misja}

Von Balthasar był przekonany, że prawdziwy obraz natury ludzkiej może zostać osiągnięty wyłącznie w perspektywie, która bierze pod uwagę Boga oraz Boży zamysł w stworzeniu świata. Częścią tego zamysłu było to, ażeby człowiek osiągnął swoją pełnię w Chrystusie. Natura ludzka jest zorientowana na to spełnienie, dlatego człowiek musi spoglądać na Chrystusa, aby poznać prawdę o tym, kim jest. Według von Balthasara człowiek jest też obdarzony specjalną zdolnością słuchania słowa Boga i to słuchanie staje się dla niego warunkiem sine qua non spełnienia siebie. Uprzywilejowanym miejscem słuchania słowa Boga jest modlitwa szczególnie kontemplacyjna ${ }^{15}$.

Von Balthasar podkreśla, że, aby słuchać Słowa w odpowiedni sposób, człowiek powinien powściągnąć akty rozumu i woli i raczej przyjąć to Słowo w świadomości, a może jeszcze lepiej całą osobą. Wiara jest „organem słuchania" i odnosi się do całej osoby ludzkiej, a nie tylko do jej poszczególnych władz ${ }^{16}$. Kontemplacja Chrystusa poprzez Pismo Święte, aby była owocna, musi spełnić trzy warunki: (1) słuchanie musi się odbywać w duchu uwielbienia, (2) należy słuchać w jedności z Kościołem i jego sakramentami, (3) słuchaniem ma kierować Duch Święty. Spełniając te warunki, człowiek może być prawie pewny, że właściwie zrozumie słowo Boże ${ }^{17}$.

„Upodobnienie się do Chrystusa”, a języku polskim także „chrystoformizacja"18, znaczy dla von Balthasara kształtowanie się człowieka w odniesieniu zarówno do Boskości jak i Człowieczeństwa Chrystusa. Czyniąc tak, teolog szwajcarski kładzie większy nacisk na człowieczeństwo Zbawiciela, niż wielu teologów przed nim. Niektórzy nazywają ten

15 V.S. Harrison, Homo Orans: von Balthasar's Christocentric Philosophical Anthropology, dz. cyt., s. 281.

16 H.U. von Balthasar, Prayer, dz. cyt., s. 180n.

17 V.S. Harrison, Homo Orans: von Balthasar's Christocentric Philosophical Anthropology, dz. cyt., s. 283.

18 Chrystoformizacja jest procesem zakorzeniania się nowego człowieka w Chrystusie. Nowy człowiek ma „zapuścić korzenie w Chrystusa” (por. Kol 2, 6-7). Por. A.J. Nowak. Psychologia eklezjalna, Lublin 2005, s. 117. 
proces „antropocentrycznym naznaczaniem modelu ludzkiej świętości”, ponieważ zawiera się w nim także relacja do Chrystusa jako Człowieka ${ }^{19}$.

W rzeczywistości relacji międzyludzkich nikt nie jest w stanie powiedzieć drugiej osobie, kim ona naprawdę jest. Nawet najbardziej empatyczne i afirmujące stwierdzenia mogą powiedzieć drugiej osobie tylko o tym, czym ona jest dla tej drugiej osoby, która ją docenia lub nawet miłuje. Dopóki człowiek nie odkryje swojej prawdziwej tożsamości, nie będzie potrafił znaleźć ani ostatecznego sensu swojej - inaczej przypadkowej - obecności na tym świecie, ani swojego zadania - misji. Bez odkrycia swojej tożsamości człowiek pozostaje zdany na względne, wzajemne i prowizoryczne relacje, gdzie uznanie jest raz dawane, a potem odbierane ${ }^{20}$.

Człowiek może odnaleźć swoją prawdziwą tożsamość dopiero w Bogu. Taki jest też dla von Balthasara cel naśladowania Chrystusa. Odnajdowanie tożsamości człowieka polega na poddawaniu własnego ja coraz bardziej powierzonej człowiekowi przez Boga misji. Właśnie poprzez tę misję, podkreśla von Balthasar, człowiek może odkryć swe prawdziwe ja, swoją prawdziwą tożsamość zarówno indywidulaną jak i społeczną ${ }^{21}$.

Wedle von Balthasara każdy człowiek jest obdarzony naturalną celowością, określonym telosem i jest stąd istotą teleologiczną. Dzięki modlitwie człowiek otwiera się na Boga, który z kolei odkrywa przed człowiekiem prawdziwy cel jego egzystencji. Przyjęcie własnego telosu dokonuje się poprzez zleconą przez Boga misję. Wyraża się ona w osobistym powołaniu i posłaniu każdej osoby ludzkiej (die Sendung), co jest dla teologa szwajcarskiego „sercem” naśladowania Chrystusa, czyli upodobnieniem się do Niego a jednocześnie odnalezieniem przez człowieka jego najgłębszej tożsamości ${ }^{22}$.

19 Por. V.S. Harrison, Homo Orans: von Balthasar's Christocentric Philosophical Anthropology, dz. cyt., s. 293.

20 H.U. von Balthasar, Theo-Drama: Theological Dramatic Theory III. Dramatis Personae: Persons in Christ, przekł. G. Harrison, San Francisco 1992, s. 205.

${ }_{21}$ Por. H.U. von Balthasar, Theo-Drama: Theological Dramatic Theory III. Dramatis Personae: Persons in Christ, dz. cyt., s. 270n.

22 V.S. Harrison, Personal Identity and Integration: Von Balthasar's Phenomenology of Human Holiness, „The Heythrop Journal” 40 (1999) Issue 4, s. 424. 
Człowiek znajduje swoje najwyższe spełnienie przez poddanie się Bogu. Spełnienie to przewyższa samą potencjalność natury ludzkiej. Spełnienie się człowieka w Bogu jest równoznaczne z odnalezieniem własnej tożsamości, tj. niepowtarzalnej misji w Chrystusie. W ten sposób życie człowieka staje się w pełni owocne. Człowiek wierny swej misji spełnia się bytowo, czego nie mógłby nigdy osiągnąć zwracając się ku głębokościom własnego ja, ku centrum swojej natury, ku podświadomości, superego, czy ku jakiejkolwiek potencjalności natury ${ }^{23}$.

\section{Człowiek zintegrowany}

Von Balthasar utrzymuje, że Chrystus przyszedł, aby przemienić ludzką naturę i połączyć ze swoim Boskim Duchem duszę człowieka, która została poddana skutkom grzechu pierworodnego, tj. pożądliwości. Jezus przyszedł, aby stworzyć nowy nous, nową psyche, nowe oczy i uszy duchowego człowieka. W śmierci i zmartwychwstaniu Chrystusa umiera stary, a rodzi się nowy, duchowy człowiek ${ }^{24}$.

Przemianę, jaka dokonuje się w człowieku dzięki Chrystusowi, można zobrazować za pomocą współczesnej metafory w ten sposób, że człowiek posiada dalej te same zmysły (hardware), ale zmienia się program ich użytkowania (software). W nowym człowieku jest to program „biblijno-kenotyczny” mówi von Balthasar. Co warte podkreślenia, przemiana prowadzi człowieka do życia czynną miłością, a dopiero wtórnie do lepszego poznania Boga. Zmysłowość człowieka zostaje odkupiona i przemieniona po to, aby postrzegał całą rzeczywistość w świetle Bożej prawdy ${ }^{25}$.

Myśl von Balthasara dobrze dopełnia komentarz W. Stinissena. Na pytanie: „kim jesteś?” ludzie zazwyczaj podają swoje dane metrykalne: imię i nazwisko, rok i miejsce urodzenia, swoją pozycję społeczną itd. Czasem mogą powiedzieć coś o swoim charakterze. Aby powiedzieć

${ }^{23}$ H.U. von Balthasar, Prayer, dz. cyt., s. 48n.

24 H.U. von Balthasar, Herrlichkeit. Eine theologische Ästhetik, I. Schau der Gestalt, Einsiedeln 1961, s. 358.

25 Y. de Maeseneer, Retrieving the Spiritual Senses in the Wake of Hans Urs von Balthasar, „Communio Viatorum” 55 (2013) no. 3, s. 285. 
więcej o człowieku potrzeba pomocy psychologa i psychiatry. Dzięki badaniom psychologicznym, choć jest to nieraz bardzo kosztowne, człowiek może dotrzeć do ukrytych pokładów swojej podświadomości, wypartych uczuć i konfliktów - może w ten sposób poznać strukturę własnej osobowości. Nie jest to jednak najgłębsza istota człowieka. To, że ktoś miał deficyty rozwojowe, że nabawił się kompleksów, czy też nie wykazuje wystarczającego stopnia przystosowania społecznego, nie dotyka najgłębszego źródła jego osoby, tego, że pochodzi ona od Boga i do Boga wraca ${ }^{26}$. Kim jest naprawdę człowiek w oczach Boga? Człowiek jest świątynią Boga (1 Kor 3, 16), nowym stworzeniem (2 Kor 5, 17), mieszkaniem Boga przez Ducha (Ef 2, 22). Zewnętrzna warstwa człowieka jest związana z imieniem i nazwiskiem, natomiast osoba głęboka posiada nowe imię nadane jej przez Boga. W Objawieniu św. Jana jest mowa o białym kamyku. (Ap 2, 17), na którym wypisane jest nowe imię. W głębi człowieka tryska zawsze źródło. Trzeba tylko do niego dotrzećn ${ }^{27}$.

Istnienie w życiu człowieka relacji z Bogiem jest dla von Balthasara formalnym warunkiem koniecznym do osiągnięcia jego pełni bytowej. Człowiek jest bytem, który sposobem swego istnienia wskazuje na coś poza i ponad sobą, co może w pełni jego życie zintegrować. Pełna integracja człowieka może się zrealizować tylko wtedy, gdy wejdzie on w świadomą relację z Bogiem. Pozostawiony sam sobie, człowiek dochodzi do paradoksów, wewnętrznych sprzeczności i zniekształceń własnej natury. Tylko w duchowej relacji ze Stwórcą, człowiek może dojść do pełnej integracji. Zakładamy przy tym, że życie zintegrowane jest w ogóle możliwe. Biorąc pod uwagę, że człowiek jest bytem zarówno materialnym, jak i duchowym; skończonym, ale i otwartym na nieskończoność; ograniczonym, ale zarazem otwartym na nieograniczoność; człowiek zintegrowany to taki, który potrafi połączyć w sobie te rozbieżne cechy. Zintegrowana osoba ludzka to ktoś, kto trwa w prawdziwej relacji z Bogiem. W celu osiągniecia pełnej integracji, człowiek jest zobligowany

26 W. Stinissen, Ani joga, ani zen. Chrześcijańska medytacja głębi, tłum. J. Iwaszkiewicz, Poznań 2000, s. 40-41.

27 Por. W. Stinissen, Ani joga, ani zen, dz. cyt., s. 47-49. 
do rozwijania w sobie głębokiej relacji z Bogiem. Osoba, która dochodzi do zintegrowania różnych elementów swojej natury dzięki relacji z Bogiem, zmierza ku świętości ${ }^{28}$.

Tylko Bóg jest w stanie dać człowiekowi prawdziwą tożsamość, co według von Balthasara jest równoważne z nadaniem człowiekowi jego niepowtarzalnej misji. Termin „osoba” przyjmuje w jego myśli znaczenie nie hipostazy, lecz właśnie misji, a idąc jeszcze dalej za metaforyką teologa szwajcarskiego, przybiera postać roli ogrywanej w Bożym dramacie (Teodramtyka). Przykładem tego rodzaju tożsamości-misji-dramatu jest dla von Balthasara Chrystus. Utożsamia się On całkowicie ze swoją misją. W Bożym dramacie Jezus jest nie tylko głównym bohaterem, ale też zarazem wzorem tego, co to znaczy znaleźć tożsamość w misji zleconej przez Boga $^{29}$. Człowiek, który na wzór Chrystusa odpowiada na Boże wezwanie w swoim życiu i przyjmuje swą misję, wyraża ją potem konsekwentnie poprzez swoje decyzje i czyny ${ }^{30}$.

\section{Człowiek święty}

Przybranie formy Chrystusa oznacza dla von Balthasara przyswojenie sobie obrazu Chrystusa, stanie się w pełni wierzącym i odkupionym człowiekiem, prawdziwym ja, na które patrzy z miłością Ojciec Niebieski. Świętość to podążanie za prawdziwym obrazem siebie w sercu Boga, czyli bycie prawdziwym sobą, co realizuje się poprzez wierność osobistemu powołaniu każdego człowieka ${ }^{31}$. Von Balthasar twierdzi, że cały byt ludzki, a więc dusza i ciało, jest otwarty na Boga ${ }^{32}$.

Upodabnianie się do Chrystusa oznacza w praktyce pełnienie, podobnie jak On, woli Ojca. Chrystus jest posłuszny Ojcu aż do „swojej

28 V.S. Harrison, Personal Identity and Integration: Von Balthasar's Phenomenology of Human Holiness, dz. cyt., s. 432-433.

29 H.U. von Balthasar, Theo-Drama: Theological Dramatic Theory III: Dramatis personae: Persons in Christ, dz. cyt., s. 201.

30 Por. H.U. von Balthasar, My Work in Retrospect, przekł. K. Hamilton i in., San Francisco 1993, s. 86.

31 H.U. von Balthasar, My Work in Retrospect, dz. cyt., s. 425.

32 Y. de Maeseneer, Retrieving the Spiritual Senses in the Wake of Hans Urs von Balthasar, dz. cyt., s. 278. 
godziny". Z Jego woli poddaje się też prawom czasowości, aby w ten sposób odkupić także czas $^{33}$. Bycie posłusznym Synem Ojca było pokarmem Chrystusa - podobnie ma nim być dla człowieka zdążającego ku świętości. Wolę Ojca poznaje się w modlitwie. Bycie świętym oznacza zatem pełnienie w posłuszeństwie dzieł, które zlecił Ojciec ${ }^{34}$. Świętość wyraża się w „dramatycznej egzystencji” człowieka, która polega na aktywnym szukaniu i pełnieniu woli Bożej, czyli na poszukiwaniu i przeżywaniu misji, którą Bóg w swej Opatrzności specjalnie dla tej osoby przewidział ${ }^{35}$.

Każdy człowiek poznaje siebie oraz kształtuje własną osobowość dzięki innym ludziom, ale pełne poznanie siebie następuje dopiero poprzez zjednoczenie z boskim Ty na szczycie osobowej samoświadomości, czy też w innym obrazie w najgłębszych pokładach ja, gdzie dzięki łasce człowiek odkrywa swe boskie pochodzenie. Rozwój osobowości osnuwa się wokół metafizycznego ja człowieka - dopowiada P. Evdokimov ${ }^{36}$.

Von Balthasar wyraża radykalną opinię w tym względzie mówiąc, że człowiek musi przejść od życia „w osobowości ku życiu w osobie”, czyli życia tym, kim człowiek jest w zamyśle Boga, co może odkryć w osobistej relacji z Chrystusem. „Osobowość musi umrzeć” - człowiek ma umrzeć w sobie „nieprawdzie”, czyli temu wszystkiemu, co stoi w opozycji do Boga - przede wszystkim pysze. Innymi słowy osobowość człowieka musi być oczyszczona z wszystkich przeszkód, które stoją na drodze upodobnienia się do Chrystusa - w języku von Balthasara na drodze „stania się prawdziwie osobą". Człowiek dochodzi do tego celu, gdy jego prawda o sobie samym staje się zbieżna z Bożą wiedzą o nim. Gdy dusza jest tak przesiąknięta prawdą Bożą, że żyje tylko tą prawdą, pozbawiona własnych wyobrażeń, staje się faktycznie pokorna, ponieważ pokora oznacza po prostu uczestnictwo w Bożej prawdzie. Pokora jest ważnym znakiem tego, że człowiek upodobnił się do Chrystusa, że pokonał

\footnotetext{
33 H.U. von Balthasar, My Work in Retrospect, dz. cyt., s. 24.

34 V.S. Harrison, Personal Identity and Integration: Von Balthasar's Phenomenology of Human Holiness, dz. cyt., s. 427.

35 V.S. Harrison, Personal Identity and Integration: Von Balthasar's Phenomenology of Human Holiness, dz. cyt., s. 434.

36 Por. P. Evdokimov, Kobieta i zbawienie świata, przekł. E. Wolicka, Poznań 1991, s. 56.
} 
powierzchowność własnej osobowości, stając się osobą wypełniająca wolę Boga, a równocześnie Go objawiającą̨

\section{Zakończenie}

Według teologa szwajcarskiego człowiek jest przede wszystkim odkupiony przez Chrystusa i poprzez Niego otrzymuje od Boga Ojca swoją misję. Przyjęcie tej misji i życie nią pozwala człowiekowi dotrzeć do pełni prawdy o sobie, tj. do osiągnięcia swojej najgłębszej tożsamości bytowej, w konsekwencji do spełnienia, a w końcu także do osobistej świętości.

Teolog szwajcarski nawiązuje do słów św. Pawła, który w jednym miejscu wspomina wyraźnie trychotomiczny podział człowieka: „Sam Bóg pokoju niech was całkowicie uświęca, aby nienaruszony duch wasz, dusza i ciało bez zarzutu zachowały się na przyjście Pana naszego Jezusa Chrystusa" (1 Tes 5, 23). W takim trójpodziale duch (penuma) nie jest wprost wykwitem ludzkiej natury. Duch jest transcendentny wobec stworzonej natury ludzkiej, jest Bożym tchnieniem (ruah). Jednak w ekonomii Bożej jedną z najważniejszych spraw stanowi usynowienie człowieka, uczynienie go swoim dzieckiem, stąd udzielenie człowiekowi Ducha Świętego jest sprawą niezwykle istotną dla Boga Ojca. W sensie teologicznym człowiek dopiero wtedy uzyskuje swą pełną tożsamość, gdy otrzymuje Ducha Bożego. W ten sposób wierzący staje się „Świątynią Ducha Świętego", który go od wewnątrz ożywia. Duch nigdy nie staje się człowiekiem, ale człowiek może stawać się coraz bardziej duchowy i jak dusza (psyche) ożywia w klasycznym ujęciu ciało (soma), tak Duch przekształca duszę. Duch jest niezasłużonym darem Boga dla człowieka i człowiek właśnie dlatego został stworzony, aby Go otrzymać. Duch nie staje się częścią duszy ludzkiej, ale punktem odniesienia, ku które$\mathrm{mu}$ ona ciąży, transcendując samą siebie. Relacja duszy do ciała i Ducha do duszy jest analogiczna. Jak ciało jest ożywione przez duszę i do pewnego stopnia sens jego istnienia jest od niej uzależniony, tak dusza

37 V.S. Harrison, Personal Identity and Integration: Von Balthasar's Phenomenology of Human Holiness, dz. cyt., s. 430. 
ma żyć w łączności z Duchem, a również i ciało ma być przez tę relację uduchowiane ${ }^{38}$.

Antropologia von Balthasara stanowi ilustrację przemieniającego procesu przyjmowania przez człowieka jego prawdziwej tożsamości. Poprzez upodabnianie się do Chrystusa człowiek staje się w pełni tym, kim w zamyśle Bożym ma być. Przyjmując od Boga zleconą misję, osobiste powołanie, staje się jednocześnie świętym Boga - czyli na wzór Chrystusa znakiem Jego obecności wśród ludzi.

\section{Bibliografia}

Bouyer L., Wprowadzenie do życia duchowego. Zarys teologii ascetycznej i mistycznej, przekł. L. Rutkowska, Warszawa 1982.

Budzik S., Dramat odkupienia, Tarnów 2007.

Cirelli A., Facing the Abyss: Hans Urs von Balthasar's reading of Anxiety, „New Blackfriars" 91 (2011) Issue 1042, p. 705-723.

De Maeseneer Y., Retrieving the Spiritual Senses in the Wake of Hans Urs von Balthasar, „Communio Viatorum” 55 (2013) no. 3, p. 276-290.

Evdokimov P., Kobieta i zbawienie świata, przekł. E. Wolicka, Poznań 1991.

Harrison V.S., Homo Orans: von Balthasar's Christocentric Philosophical Anthropology, „The Heythrop Journal” 40 (1999) Issue 3, p. 280-300.

Harrison V.S., Personal Identity and Integration: Von Balthasar's Phenomenology of Human Holiness, „The Heythrop Journal” 40 (1999) Issue 4, p. 424-437.

Jastrzębski A., Inspiracje teologii Hansa Ursa von Balthasara, „Filozofia Chrześcijańska" 13 (2016), p. 121-134.

King J.S., Shea C.M., The role of Nikolai Berdyaev in the early writings of Hans Urs von Baltasar: A contribution to the question of Balthasar's appropriation of sources, "Journal for the History of Modern Theology / Zeitschrift für Neuere Theologiegeschichte" 21 (2014) Issue 2, p. 226-257.

Nowak A.J., Psychologia eklezjalna. Lublin 2005.

Piotrowski E., Toedramat, Kraków 1999.

Pyc M., Chrystus Piękno - Dobro - Prawda, Poznań 2002.

Sawicki B., Ekspresja jako spotkanie chrystologii i antropologii, Tyniec 2019.

Stinissen W., Ani joga, ani zen. Chrześcijańska medytacja głębi, tłum. J. Iwaszkiewicz, Poznań 2000.

Balthasar H.U. von, Epilog, przekł. J. Zychowicz, Kraków 2010.

Balthasar H.U. von, Herrlichkeit. Eine theologische Ästhetik, Band I. Schau der Gestalt, Einsiedeln 1961.

38 L. Bouyer, Wprowadzenie do życia duchowego. Zarys teologii ascetycznej i mistycznej, dz. cyt., s. 103. 
Balthasar H.U. von, My Work in Retrospect, ed. K. Hamilton, San Francisco 1993.

Balthasar H.U. von, Prayer, ed. A.V. Littledale, London1961.

Balthasar H.U. von, The Glory of the Lord, vol. 1: Seeing the Form, ed. E. Leiva-Meriikakis, San Francisco 1983.

Balthasar H.U. von, Theo-Drama: Theological Dramatic Theory III. Dramatis Personae: Persons in Christ, ed. G. Harrison, San Francisco 1992. 